\section{Bleek planeet.}

Dolf van Niekerk.

Pretoria: Protea Boekhuis, 2013. 61 pp.

ISBN: 978-1-8691-9921-0.

DOI: http://dx.doi.org/10.4314/tvl.v51i2.25

Dolf van Niekerk is welbekend as skrywer van romans, kinder- en jeugliteratuur en poësie. Sy skrywersloopbaan strek oor meer as 'n halfeeu, met hoogtepunte soos Die son stuikel (1960) en die digbundel Nag op ' $n$ kaal plein (2006). Bleek planeet (2013) is sy vyfde digbundel en dié bundel word deur vele kritici beskryf as ekobewuste poësie, soos die flapteks dit stel: "Hy verwoord hierin sy verwondering oor die ontstaan van die aarde, sy liefde vir die kwesbare, droë dele van ons land, veral die Karoo, en 'n diep kommer oor die kragte wat die fyn balans van die natuur kan versteur." Eietydse ekologiese problematiek soos aardverwaming, hidrobreking ("fracking") en verskynsels soos el niño word betrek. Aardverwoesting, natuurverskynsels en die geïmpliseerde rol van die mens as (dikwels gefaalde) behoeder van die natuur word in hierdie bundel met deurdagte en suggestieryke taal onder woorde gebring.

In Bleek planeet werk heelwat van die gedigte intertekstueel. Daar is onder meer geografiese, religieuse en musiekintertekste, asook verhale van geskiedkundige figure en gebeurtenisse.

Twee belangrike intertekstuele rame wat behendig lig werp op die bundelinhoud is die bundel se motto en die gebruik van 'n Dylan Thomas-gedig as aanwysing in die gedigsiklus "Nuwe Seisoen". Hierdie intertekste beklemtoon veral die tematiese kern van die bundel en die tweeledigheid waarvolgens die verse ontvou.

Die subtitel van die eerste gedig van "Nuwe Seisoen" is die openingsversreël van Dylan Thomas se veelbesproke gedig "The force that through the Green Fuse Drives the Flower...". Dié subtitel word deur'n ellips opgevolg, wat die res van die eerste strofe van Thomas se gedig kan impliseer:

"The force that through the green fuse drives the flower / Drives my green age; that blasts the roots of trees / Is my destroyer"

In Thomas se gedig word die lewegewende krag ("force") wat aan die blom lewe skenk, gelykgestel aan die krag wat die wortels van bome uitmekaarskiet. Die sikliese saambestaan van die vernietigende ("Is my destroyer") en lewensgewende aard van die natuur word deur die Thomas-interteks vooropgestel. Dieselfde natuurkrag wat in Thomas se gedig vernietigend en lewegewend werk, is ook een van die sentrale beginsels van Bleek planeet. Weemoed en uitsigloosheid in die aangesig van die versteuring van die natuur se harmonie, ontvou in die bundel tesame met 'n ondertoon van die wete dat hoop, lewe en die begeerte na 'n nuwe begin sal bly voortbestaan. Die pragtige gedig "Tuinier" getuig byvoorbeeld van dié bewuswording:

wit skoenlapper vlieg vanoggend

teen my borskas vas

en al die lentes van my jare

flakker oop-

blydskap en verdriet in klank en kleur

gevang, 'n mengeling van groei

en blom en sterf in ewewig vas.

Die bundel kan dus in terme van opposisiepare gelees word: lewe en dood; einde en begin; verlede en toekoms. In die geval van laasgenoemde is daar dikwels in die gedigte ' $n$ teruggryp na die verlede, daar word onder meer verwys na die oerbestaan van die aarde ("Garob", "Osoon"), die Antieke Grieke ("Oikonomos", "Mastos"), die Khoi ("Garob") en die verhaal van See-at-hl ("Elegie vir verlore aarde"). Die ewewig in die opstel van opposisiepare word egter behou met vooruitwysing na die ("bleek") toekoms, soos byvoorbeeld in die openingsgedig " 2111 ".

Die intertekstuele raam van die reeds 
genoemde Thomas-gedig belig ook ' $n$ ander belangrike beginsel van die bundel, naamlik die noue verband tussen mens en natuur wat reeds prominent is in "2111": "Ek praat met die bome, / voel hul stuwing deur my vel". Die spreker in dié gedig eien ook die natuur: "my bos", "my boom se kaal verdriet" en die suggestie lê daarin dat dit juis die mens se grypsugtige eienaarskap van die aarde is wat veroorsaak dat die aarde in die toekoms, dalk 2111 , gereduseer gaan word tot ' $n$ "museumstuk in die ruim".

In aansluiting hierby stel die motto van die bundel, in die woorde van Václav Havel, dat 'n gebrek aan 'n revolusie in menslike bewussyn op 'n onafwendbare ramp afstuur: "Without a global revolution in the sphere of human consciousness, nothing will change for the better in the sphere of our being as humans, and the catastrophe towards which this world is headed - be it ecological, social, demographic or a general breakdown of civilization-will be unavoidable."

Waarop dit neerkom, is dat hierdie bundel verhoudings verken - die verhouding van die mens en die natuur, dikwels raaiselagtig en mistiek; die verskillende natuurkragte wat op mekaar inwerk, asook hoe dit in verband staan tot ' $n$ groter heelal. Op dieselfde wyse word daar besin oor die bestaan van die gedig en die mistiek van die skryfproses, soos in die slotgedig "Braambos":

wat is jy blom

ek is die halfpad-woord

wat jy nie kan voltooi

maar met skryf

en praat in brabbeltaal

moet swoeg om die sin

van woorde te verhaal

Daar bestaan vele en dikwels ooglopende aspekte wat in Bleek planeet eenheidgewend werk: Die deurlopende stemmingsrykheid, die tematiese samehang en geslaagde leitmotiewe, om enkeles te noem. Ook verras die aanbieding van 'n metapoëtiese ondertoon in die bundel, waar die skryfproses telkens in verband gebring word met die boormetafoor, wat weer eietydse problematiek soos hidrobreking oproep ("snags boor ek"):

snags boor ek

na die oergesteente

van die Groot Karoo

en elke dagbreek

bid ek droë woord op

Daar is ' $n$ hele aantal hoogtepunte in Bleek planeet, gedigte wat spreek van besondere metafoorgebruik en beleë taal, soos "Ballade van die hande", "Tuinier", "Brandskilder", "Brandskilder II" en "25/12". Die besondere "25ste uur" is gestroop en ryk aan assosiasies: wit skoenlapper tuimel van nêrens op 'n wit blom by Carnarvon sy fladderhang versteur die ewewig die aarde kantel stort die blom die duikelaar kring om en om die ruimte van verlore lig

Kritiek kan egter uitgespreek word oor die beskuldigende toonaard van sommige gedigte, wat soms neig tot'n ekopolitiese cliché. Hier kan gedeeltes van die postkoloniale gedigreeks "Elegie vir verlore aarde" genoem word:

Groot Witte, jy vra én steel my land, jy breek die web van God of dit jóú spinsel is, praat of $\mathrm{Hy}$ die weerklank van jou gryplus en die maker van jóú nuwe wêreld is.

"Elegie vir verlore aarde" bied ter verdediging versreëls wat ook raakvat: 
Elke wond wat ek nou slaan,

al die pyn wat ek die aarde ly

sal eendag in my lyf kom staan-

dat ek te laat sal weet: Die aarde

is nie van my nie maar ek is van sy stof.

Van Niekerk se bekende gestroopte, ingetoë en veral suggestieryke styl sorg deurgaans vir 'n aangename leeservaring. Hierdie bundel is nie alleen vir natuurliefhebbers nie, maar vir elkeen wat die ryp poësie van 'n deurleefde digter geniet, elkeen wat met die lees van poësie gestem wil word tot nadenke oor die mens se verbondenheid tot die wonderlike en verwonde natuur.

Ihette Jacobs

jacobsi@ufs.ac.za

Universiteit van die Vrystaat

Bloemfontein 